\title{
Jesus' kingdom parables as metaphorical stories: A challenge to a conventional worldvieu'
}

\author{
Dieter Reinstorf \& Andries van Aarde \\ Department of New Testament Studies (Sec A) \\ University of Pretoria
}

\begin{abstract}
Jesus' parables are to be read as metaphorical stories. Parable as metaphor demands that the parable remains open-ended and polyvalent, with the reader always inwolved in a participatory role. This article aims at showing that Jesus' kingdom parables are of a diaphoric, nature challenging the conventional worldview. It focuses on the parable 'A Man Had Two Sans' (Lk 15:11-22). This parable is interpreted from the $\mathrm{Lu}$ can perspective. It shows how the mytheme of the 'two-sons stories' is used as a tensive symbol in order to establish the Lucan notion of the allinclusiveness of God's kingdom.
\end{abstract}

\section{INTRODUCTION}

Within parable research a marked shift has taken place in recent years. This shift can largely be attributed to two factors. First, primarily as a result of the work done by literary theorists, there has been a renewed awareness of the narrativity of the gospels in general and of the parables in particular. Second, there has been a rediscovery of the meaning and value of metaphor as an appropriate vehicle for speaking about God and conveying alternate views on reality. Parables are read as metaphorical stories which challenge a conventional worldview.

The above-mentioned shift is parallelled by new epistemological insights. Literary theorists have proposed a form of critical realism, whereby knowledge is gained in the dialogue and interaction that takes place between an observer (reader of a text) and the object (the text itself). This dialogue stimulates a response and agitates the mind into fresh and creative thinking leading to new insights.

It is my conviction that explicating Jesus' kingdom parables as metaphorical stories within the broader framework of a critical realistic epistemology will give a new and dynamic dimension to parable research with existential significance.

\footnotetext{
* This article is based on the author's M Div thesis (1997). The thesis, with Prof Dr A G van Axrde as promoter, was submitted as part of the requirements of the M Div degree, Faculty of Theology (Sec A), University of Pretoria. Rev D H Reinstorf is pastor of the Evangelisch-Lutherische Petrusgemeinde in Greytown, South Africa.
} 
After giving a broad overview of the shifts that have taken place in parable research and epistemological models, a single kingdom parable will be interpreted in an exemplary way with the distinct aim of recognizing the symbolism of the kingdom and its challenge to a conventional worldview. In order to capture the metaphorical thrust of the parable, special consideration will be given to the social environment of firstcentury Palestine.

\section{A BROAD OVERVIEW OF THE HISTORY OF PARABLE INTERPRETA- TION}

The emphasis today on the metaphorical nature of parables is not arbitrary, but correlates with an emerging paradigm shift. This correlation is not confined to the present period, for a study of the history of parable interpretation shows that there is a distinct relation between the dominant scientific paradigm and hermeneutical schemes used to interpret parables. The awareness of paradigm shifts is attributed to Thomas $S$ Kuhn, who defines a paradigm as a conceptual framework, a worldview, in terms of which a particular scientific community researches that part of reality of interest to it (cf Mouton \& Marais 1996:145). When a dominant paradigm no longer offers satisfactory solutions to problems being researched, it leads to a crisis and to a scientific revolution resulting in the emergence of a new paradigm.

Within the scientific community increasing reference has been made to three dominant paradigms: Vitalistic, Mechanistic and Holistic Paradigms (Martin 1987:372). Although not completely distinct from the one paradigm continuing in the era of the next, they are distinguishable. The Vitalistic Paradigm was dominant from the period of the New-Testament to the end of the sixteenth century. It is the paradigm of organic life and growth. This period is characterized by a harmony between human beings and the world around them, with God forming an integral part of this world. Biblical interpretation associated with this paradigm is symbolic, with every created thing referring symbolically to its heavenly reality (Martin 1987:375).

Within parable interpretation this led to an accentuation of allegorical meaning. Signs of allegorical interpretation can be traced back to the evangelists themselves (cf Mk 4:13-20 and paralleis), who, in applying Jesus' parables to their specific situations, made use of allegory at times (Kissinger 1979:76). Allegorical interpretation became a general feature amongst biblical interpreters following Platonism (Pelser 1994:11). During the period from the Early Church until the late Middle Ages, interpreters were guided by the perception that a text has at least a dual meaning: sensus litteralis and sensus spiritualis. Although there were times when either the sensus litteralis or the sensus spiritualis enjoyed precedence, the Bible was continually approached with the notion of having a dual meaning. 
Typical of this period's allegorical parable interpretation is Augustine's exposition of the parable of the Barren Fig Tree in Luke 13:6-9 (cf Kissinger 1979:19). According to him the fig tree is the human race. The three years the man comes to look for fruit are three periods of time: before the law, under the law, under grace. Sin is the reason why the human race could not bear fruit. As a result of its unfruitfulness, the axe hangs over the tree. The gardener, however, intercedes. Punishment is deferred so that help may be given. The gardener is every saint within the church who prays for those who are outside the church. The reference to cutting down the tree if it does not bear fruit signifies the coming of Christ in judgement. The digging of the garciener has to do with the teaching of lowliness and repentance. The manure is filthy, but it produces fruit. The gardener's filth is the sinner's sorrow. Augustine's interpretation ends with a teleological conclusion, typical of this period, addressed to the human race: 'Repent ye, for the Kingdom of Heaven is at hand' (Mt 3:29).

It is widely accepted that the Mechanical Paradigm, beginning with Galileo, Descartes and Newton, stretches from the seventeenth to the latter half of the twentieth century (Martin 1987:374). It is the paradigm of mechanical change. The emphasis lies on the machine and its many parts. Biblical interpretation associated with this period is predominantly analytical. Knowledge is achieved by breaking down an object into its constituent elements. Interpretation seeks the causal and genetic origins of a given whole, assigning priority to parts over wholes, and to earlier forms or parts over later parts (Martin 1987:375-376). This kind of exegesis found its culmination in the early period of historical-critical research with its vivid interest in the parts underlying and constituting a text. Also the single word is scrutinized. Theologians seek to identify the Grundbedeutung (original or earliest meaning) of a word with the assumption that it will lead them to a proper meaning on the basis of which further theological deductions can be made. Although the analysis associated with this period has proved highly effective with regard to detail, the larger picture is often obscured as a result of the process of fragmentation.

Within parable research Adolf Jülicher's epoch-making book Die Gleichnisreden Jesu in 1886 and 1899 (cf Kissinger 1979:72; Scott 1989:42) stands out. Jülicher's work is primarily an attack on the allegorical and moralistic interpretation of parables and he insists that the essence of the parable is similitude, a comparison. According to Jülicher a similitude is an expanded simile, a Vergleichung, which consists of two parts in relationship with one another, Sache - the reality being represented, and Bild - the figure representing the reality. These two parts are bridged by the tertium comparationis - the third item of comparison, which constitutes a parable's point (cf Scott 1989:43). This is a clear rejection of the multiple-points methodology of the allegori- 
cal interpretation of parables, in favour of a single-point methodology. The single point in the parable of the Talents (Mt 25:14-30), for example, relates to faithfulness in every trust; the parable of the Unjust Steward (Lk 16:1-8) shows that the wise use of the present opportunity is the best preparation for a happy future, and so on.

Since Jülicher, most parable interpreters have, in accordance with the mechanical paradigm, searched analytically for that single point of comparison in the parables of Jesus. The major works of both $\mathrm{C} \mathrm{H}$ Dodd and J Jeremias reflect this methodology. The search for the single point of comparison is parallelled by the search for the single situation of the parable (cf Scott 1989:43). Parables are tied to a particular situation, the Sitz im Leben, in the ministry of Jesus. Every effort is therefore made to recover the historical setting of each of the parables with all necessary historical information concerning the individual features. Jeremias' Die Gleichnisse Jesu is accordingly introduced by the sentence: 'Wer sich mit den 41 Gleichnissen Jesu ... beschäftigt, steht auf besonders festem historischen Grund ...' (Jeremias 1970:7).

The emerging Holistic Paradigm is a '( $p$ )aradigm of process, evolutionary structure and connecting patterns' (Martin 1987:373). It is characterized by the quest for wholeness. Studies on the processes of how parts come to form wholes have shown that the sum of the parts does not always constitute the whole. Furthermore, the awareness has emerged that everything is related to everything else and that in order to know something it is imperative to understand how it relates to something else. This had led to a number of new questions. The who, where and the what questions of the Mechanical Paradigm are supplemented by the why question: Why did or does something or someone behave or react in a certain way?

The Biblical interpretation associated with this period is holistic. The movement is from the whole to its parts. Martin refers to a statement made by Ernst Fuchs that there are two ways to study a cat: cutting it up on the dissecting table or watching a live cat with a mouse (Martin 1987:376). If the cat were replaced with a Bible, most Biblical interpreters of the present holistic period would prefer the latter style of observation. The reason for this is the emergence of a new perception of text: that it is alive, rather than dead. Should this perception be valid, the analytical interpretation of a text associated with the mechanical period is indeed limited in the knowledge it can supply. Emphasis is placed on the whole story of a text and the whole process of communication. Being alive, a text evokes emotions, feelings, acts on us and communicates differently within a differing context. The area of research today is therefore primarily literary, with an emphasis on narrativity. In view of changing contexts, historical analysis remains an essential part of an exegete's approach. But, in contrast to historical analysis within the mechanical paradigm, historical analysis now focuses on 
the total society in which a text is set. Economic, political, social and cultural facts are all relevant to an understanding of a text, with the exegete featuring in a participatory role.

With the emphasis placed on the performative aspect of language, parables were viewed by the proponents of the New Hermeneutics, a movement of post-Bultmanian scholars, as language events (cf Kissinger 1979:xiii-xiv; Perrin 1976:111-112). Parables are not restricted to their single historical situation in the past, but have the capacity of generating fresh relevance in today's situation, challenging and confronting the reader with the necessity for decision. As language events, Jesus' kingdom parables do not only explain in new conceptual terms what the Kingdom of God is about, but draw the reader into their world of existence and create the possibility of the reader sharing in it.

From language as events the focus has moved on to an analysis of the literary form of parables. Especially in North America, New Testament scholars are in conversation with literary scholars. An awareness has emerged that a text is inseparably related to the form and purpose of its language and that it is not enough to interpret the parables of Jesus solely in moral, theological or historical terms. This has led to new consideration being given to the nature, function and power of metaphor, and its ability to engage the hearer as participant, with both the speaker and the hearer operating within the parameters of their society. The argument that parables are metaphors has subverted the single-point methodology and has led Robert Funk (1966:151) to conclude that a parable may have "many points", as many points as there are situations into which it is spoken.' The focus in parable research has, in accordance with the holistic paradigm, clearly widened to include many new and exciting dimensions.

\section{THE METAPHORIC NATURE OF JESUS' KINGDOM PARABLES}

Metaphor is not a new term in parable interpretation. Since Aristotle the term metaphor features in some or other way. For Aristotle a metaphor is an unfamiliar word used in the place of a familiar word (cf Du Toit 1984:68). In order to understand the metaphor, one must replace it by another word. According to this definition, a metaphor is, strictly speaking, a figure of speech with ornamental value confined to single words. Once the unfamiliar word is replaced by the familiar word, the metaphor ceases to exist. The Aristotelian view determined metaphorical perception throughout both the vitalistic and mechanical periods. Allegories were regarded as metaphors, with allegorical parables, like the parable of the Sower, consisting of a number of metaphors strung together to form a coherent narrative. 
Recently scholars have become aware that metaphor is not merely a figure or speech; nor is it confined to single words, but can consist out of short discources or narratives. New advances were made by Amos Wilder, a New Testament scholar as well as a poet and authority on general literary criticism. Wilder (1971:xxi-xxv) notes that in contemporary literary criticism attention is directed to the work to be interpreted as a self-sufficient aesthetic whole. Parables are art-works like poems. Although originating from a specific historical situation, they transcend that situation. Furthermore, they convey not only certain truths but visions of reality, which are, in turn, the essence of metaphor. Wilder (1971:71-77) describes a true metaphor as more than a sign; it is a bearer of the reality to which it refers and as such draws the hearer into its world as an active participant.

Robert Funk's work reflects the insights gained from Wilder. Whereas in the past metaphor functioned primarily as a substitutive, Funk (1966:138) is interested in the metaphor as an additive, an instrument of knowledge creative of meaning. To explain what a metaphor is, Funk (1966:137-138) makes use of the literary distinction between a simile and a metaphor. Both have an element of comparison. In a simile $A$ is like $B$. In a metaphor $\mathrm{A}$ is $\mathrm{B}$. The saying, 'The Kingdom of God is like ...' is a simile, whereas the saying, 'The kingdom of God is ...' is a metaphor. For Funk the grammatical difference is irrelevant; it is a question of how the parables of Jesus function. As the word 'like' implies, the simile functions to illustrate an entity. A metaphor does not illustrate but represents that entity. As in Jesus' parables two discrete and not entirely comparable entities are often juxtaposed, the juxtaposition produces an impact on the imagination of the hearer which leads to new meaning. Meaning is contained in neither A nor B, but is effected in the juxtaposition. As metaphors, Jesus' parables are therefore not simply didactic stories illustrating a single historical, moral or theological point (mechanical paradigm), but are artistic, mind-pricking speech, bearing ontological reality.

In focusing on the issue of metaphorical parables and kingdom, as in Jesus' kingdom parables, insights of Norman Perrin are valuable. Historians have always had a conceptual understanding of kingdom. Parable interpreters in general understood kingdom in terms of an apocalyptic concept of the new age within the temporal dualism of present and future, here and yet to come. Although Perrin initially shared this position, he later rejected the Kingdom of God as concept in favour of the Kingdom of God as symbol (Perrin 1976:33). Important in Perrin's understanding of symbol is the distinction between tensive and steno symbols, which he borrowed from Peter Wheelwrigth (Perrin 1976:29-33). A steno symbol has a one-to-one relationship with what it represents. A tensive symbol represents a set of meanings, which cannot be exhausted 
nor adequately expressed by any one referent. For Perrin kingdom is clearly such a tensive symbol in the language of Jesus' kingdom parables. The difference between an understanding of kingdom as a concept and as a symbol is decisive. If it is a concept, it is grasped cognitively and can be conveyed in normal, discursive speech. However, if it is a symbol, it is connotative language, with the signified always slightly blurred and not fully graspable.

Parable as metaphor demands that the parable is never done away with. The parable remains open-ended and polyvalent, with the readers always involved in a participatory role. They are drawn into the world of the parable through which they then view their own world. In order to grasp the world of the parable it is imperative for the exegete to focus holistically on the total society in which the parable features.

\section{A BROAD OVERVIEW OF EPISTEMOLOGICAL VARIANCES}

A holistic approach to parable research demands critical reflection on epistemological theories. Epistemology has to do with how people know things. Within the so-called pre-critical, vitalistic paradigm this question was hardly debated. Everything was assumed to be true at face value, with the ideas in our minds and the knowledge that we have corresponding directly with the world as it is. One might fairly say that critical epistemological reflection has its roots in the period of the mechanical paradigm.

René Descartes is widely accepted as the father of modern philosophy. Descartes influenced modern thinking in the West to such a degree that his form of thinking is often regarded as the only form of rational thinking. A legacy attributed to Descartes is the split between subject and object, which has led to what Ted Peters (1992:9) calls the 'principle of distanciation'. Everything is observed from a distance - with the subject, human being, in a neutral observer status, totally separated from the object, the world it observes. Under the influence of Descartes it was assumed that everything can be objectified, even truth. Peters (1992:9-10) writes: 'Descartes formulated the question of truth as if the truth had nothing to do with himself ... . He implicitly cedes the content of truth to the objective world and not to himself as a subject'. Within the philosophy of science this has led to the epistemological theory of positivism (cf Van Huyssteen 1989:3-10; Wright 1992:32-35).

The positivists believe that there are some things that are simply objectively true and about which we can have irrefutable knowledge. These are things which can be tested empirically within the real world and arranged logically into a unitary system. What cannot be tested in this way is reduced to subjectivity or relativity and is not true knowledge. Positivistic scientists share a dual assumption. They assume that factual, value-free observation is possible, without prejudice and without cultural, political, or 
religious distortion, and that one can go directly from observation to theory. From positivistic theologians one will often hear the complaint that while other people have presuppositions, or make extensive use of models, they simply read the text.

Phenomenalism forms the obverse of positivism, but both are products of the modern mind. In stark contrast to the positivists, phenomenalists believe that human knowledge is confined to the appearances presented to the senses (cf Wright 1992:35). In other words, the only things of which I can really be sure, is what $I$ feel, or how $I$ perceive something. Instead of proclaiming 'this is the way it is', one would rather state 'this is the way $I$ see it', or 'this is the way it is to me, but it could be different to you'. Wright (1992:35) reflects critically on these two contrasting theories by means of the following illustration: 'If knowing something is like looking through a telescope, a simplistic positivist might imagine that he is simply looking at the object, forgetting for the moment the fact that he is looking through lenses, while a phenomenalist might suspect that she is looking at a mirror, in which she is seeing the reflection of her own eye'.

Scholars both from the natural sciences and the humanities have begun to question the dichotomy created by the positivist and phenomenalist views and the resulting polarity between objective and subjective knowledge. Can one really distinguish clearly between the subject and the object? Is 'true' knowledge really confined to what can be objectively verified? Or, for that matter, does subjectivity exclude any form of 'real' knowledge? Within the emerging holistic paradigm with its emphasis on the whole, an awareness of the interrelationship of all things has grown. Peters (1992:11) writes: 'Critical distance through objectification has made us forget that there is only one reality that includes both external objects and human subjects in relation to one another.' It has become clear that there is no such thing as an 'objective', or a 'neutral', or 'detached' observer. The observer always forms part of the whole; and his or her personal feelings, inclinations, perspectives, and biases are just as real as the object being studied. To prevent a diminution of truth, it is imperative that truth must include the human subject.

Recently the epistemological theory of critical realism has emerged. Critical realism in itself is a wide-ranging subject, a detailed discussion of which would extend beyond the scope of this essay (cf Van Huyssteen 1989:125-197; Meyer 1989). Our discussion will focus on critical realism as proposed by Thomas Wright. He gives the following definition: 
This is a way of describing the process of 'knowing' that acknowledges the reality of the thing known, as something other than the knower (hence 'realism'), while also fully acknowledging that the only access we have to this reality lies along the spiralling path of appropriate dialogue or conversation between the knower and the thing known (hence "critical').

(Wright 1992:35)

Central to Wright's understanding of critical realism are two aspects. First, the interrelation between the observer (the knower) and the object being observed (the known thing), and second, the larger framework in which this interrelation takes place.

Knowledge is confined neither to the observer nor to the object being observed, but takes place in the continuing dialogue between the two. Presupposed is that the object is indeed an identity separate from the observer, with a life of its own, but although separate, the knowledge that takes place is never independent of the observer. After the initial observation of the object, the path therefore leads by critical reflection back to the observer. Critical reflection takes into account that the observer is always looking from only one point of view. There is no such thing as a god's eye view. The point of view of the observer is influenced by two factors. First, we naturally interpret the information received through a grid of expectations, memories, personal questions, and so on. Second, the lenses through which we look at the object have a great deal to do with the communities to which we belong, their social, political, and religious traditions. After the initial observation has been challenged by the critical reflection, the spiralling path moves back to the object and thus leads to a thorough knowledge of (the external) reality by means of careful listening and real understanding. As this knowledge is not separated from the observer, it is always provisional in nature, open and dynamic within a changing context.

The knowledge that gained in the to and fro between observer and object does so within the larger framework of stories or worldview (Wright 1992:37). In short, worldview can be defined as the grid through which we perceive reality, or the way of being in relation to the world. Positivistically conceived, knowing therefore does not take place upwards from the empirical data, cautiously and critically verified, to confident statements on reality, but within a larger 'whole', the grasping of larger realities. In the conversation between observer and object, the observer's worldview is challenged. Knowing takes place when we find things that fill in gaps, solve puzzles, or make more sense to our way of being in relation to the world. 
When critical realism is specifically applied to the reading of text and literature, the different presuppositions of the theories discussed above are very apparent (cf Wright 1992:65-66). The positivist regards literature as the neutral description of the world. The phenomenalist regards literature as a collection of subjective feelings. The positivist says the purpose of criticism is to establish the right or true meaning of the text, and assumes that there is such a truth and that it can be found. The phenomenalist says that there is only my reading, your reading and an infinite number of other possible readings. The critical realists conceives literature as the articulation of worldviews, or better still, the telling of stories which bring worldviews into articulation. These stories are potentially different from the reader, and once spoken or fixed in writing, also potentially independent of the author. In reading literature, the reader enters into conversation with the text. His reading seeks to be true to itself, and to the public world, while always open to the possibility of challenge, modification, and subversion.

\section{STORIES, WORLDVIEWS AND THE PARABLES OF JESUS}

The way we perceive and experience reality is conveyed to others through conversation and actions: that is what we tell each other and the way we live within a particular community. Both 'are narrative in nature. Accordingly Wright (1992:38) postulates that 'stories are one of the most basic modes of human life.' Humans tell each other stories. Stories are not just a substitute for the real thing; they cannot be pealed off with the assumption that then the true facts are laid bare. Instead they are a vital element in the construction of worldview. They are the vehicle through which worldviews are manifested and form the framework for experiencing the world. This framework cannot simply be done away with.

That stories are a fundamental characteristic of worldview is illustrated by Wright (1992:39-41) in relation to the worldview of the biblical writers and its many variances. The documents in the Old Testament have without doubt the substructure of story. A story is told of the covenant God, the world, and Israel. In this story the worldview of the Israelites finds expression. This primary story is often complemented by secondary stories. These stories serve as an encouragement and underline the already expressed worldview. Stories are, however, also a very good means of modifying or subverting other stories and their worldviews. A classic example is the story told by Nathan to David in 2 Samuel 12:1-4 about the rich man, the poor man and his little lamb. Nathan does not confront David directly in discursive speech, instead he tells David a story. The story comes close enough to the world of David that a spark jumps which leads to insight, remorse and repentance. Similarly a small group of Israelites in first-century Palestine began to tell a new story, a variant to the con- 
temporary worldview of that period. Their story represented another way of looking at the world. They retold the story of Israel as they saw it compressed in the story of Jesus. By telling their story, they affirmed that the hope which characterizes their worldview has been fulfilled in the Jesus-event.

A story that articulates worldview is by nature always normative, professing to be a story which makes sense of the whole reality. Whether such a story is accepted depends on whether it makes more sense than other stories that may be on offer. Essential to an understanding of the function of story is its power to change how people think, feel and behave, and hence can change the way the world actually is.

Wright's insight that worldviews are articulated by stories, is fundamental to the understanding of Jesus' parables. Jesus' parables are stories. Jesus took well-known scenarios from everyday life and retold and moulded them into his own story. By telling stories, metaphorical in nature, Jesus was challenging a conventional worldview and inviting his hearers to accept a new worldview. His stories imply that the everyday perception of the world, certified by everyday experiences, is false, misleading, and inhibit life. There is another dimension of reality. This other dimension is not figurative, but real, and it is not apocalyptical in nature, but present now. In the language of Jesus this new reality is called the 'Kingdom of God'. The parables mark the 'frontier' of this new reality (Funk 1996:169). And by mediating this reality, they help those on this side of the frontier to cross over to the other side. The crossing of the frontier is not initiated by a moralistic demand for submission, but by the stories' invitation to engage in dialogue and conversation, 'consider seeing it this way'. By their nature parables are therefore always open-ended. The closed ending of some of Jesus' parables in the New Testament reflect the interpretation and application of those parables by an evangelist within the macro-text of the particular Gospel.

With regard to the interpretation of Jesus' parables, the awareness of their story-like nature leads to a revised and more holistic methodology. Firstly, the story as a narrative whole must receive attention with a focus on the structure of its language and its functionality. What effect did it have on its real or implied listeners? What feelings, emotions, and expectations did it raise? In allowing the story to have preference, the interpreter will have to guard critically against domestication. The story may not be made to conform to some established paradigm of meaning in the mind or community of the interpreter, nor may it be reassimilated to the everyday outlook of the first listeners (Funk 1996:184). Secondly, as worldviews are anchored in society and in order to become aware of the metaphorical thrust of the parable, our historical focus needs to widen to include the total society in which the parables featured. The parables must be interpreted within their own world: first-century advanced agrarian society 
embedded in the eastern-Mediterranean society (cf Lenski, Lenski \& Nolan 1991:169196; Herzog 1994:53-73). Thirdly, from the parable's juxtaposition to its referent, the interpreter needs to discern the challenge with which a contemporary worldview is confronted.

\section{PARABLE EXPOSITION}

The scope of this paper will allow no more than the exposition of one of Jesus' kingdom parables. The parable of the Prodigal Son in Luke 15:11-22 will be analysed in an exemplary way. The analysis will focus primarily on Bernard Brandon Scott's influential work Hear then the parable. Scott (1989:100) entitles this parable 'A Man Had Two Sons'.

Whether the parable of A Man Had Two Sons is classified as an example story, a similitude, or an allegory makes no real difference. The emphasis placed on narrativity and metaphoricity has led to a critical reassessment of the traditional historical-critical classification of parables (Scott 1981:23-24; Van Aarde 1994:235-239). Van Aarde (1994:236) argues that all parables should be referred to as metaphorical narratives. Similarly Scott (1981:24) distinguishes only between narrative parables, and one-liners, both being metaphorical in nature.

In Hear then the parable Scott organizes the parables under three headings based on a social map of first-century Palestine: 'Family, Village, City, and Beyond', 'Masters and Servants', and 'Home and Farm'. The social map tells people who they are, who they are related to, how to react and to behave. Scott argues that 'this social map fumishes a metaphorical system for envisioning the kingdom of God' (Scott 1989:79). The family, with the father as the focal point, formed the centre of the map; followed by the village, the city and beyond, that is the social world of the elites and the ruling class. The parable of A Man Had Two Sons falls into the group of family parables. Using an everyday reality like the relationship between a father and his family Jesus opens doors to an alternate construction of reality, in which God rules. According to Jesus, this reality is obscured by the actions and events of the accustomed world. In order to create awareness of this alternate reality, Jesus although using everyday events, often jolts his listeners by juxtaposing apparently non-comparable entities.

In reading the parables of Jesus, as in all metaphors, one needs to distinguish between what Peter Wheelwright has called an epiphor and a diaphor (cf Du Toit 1984: 100-101). In an epiphor the emphasis is on Anschaulichkeit. Two comparable entities are juxtaposed, so the unfamiliar entity is visualized on the basis of the familiar entity. If an interpreter reads a parable as an epiphoric story he seeks to identify the elements of similarity. The parable of A Man Had Two Sons has often been read as such an epi- 
phoric story. As such, true repentance, for example, is visualized on the basis of the words and actions of the younger son returning to his father; or true love is visualized on the basis of the unconditional acceptance of the younger son by the father. In a diaphor, however, two contrasting entities, with no apparent resemblance, are juxtaposed. The paradox agitates the mind and serves as a catalyst for the reader to think something new. In this exposition, the parable of A Man Had Two Sons will be read as a diaphoric story in which the contrasting elements are accentuated.

\subsection{The parable of A Man Had Two Sons}

The reading of the parable of A Man Had Two Sons, as with any parable, can take place on different levels, corresponding to the Sitz im Leben. The parable can be read on the level of the historical Jesus, situated in Galilee at the time of Jesus himself. An excellent exposition of the parable on this level is given by Robert Funk (1996:181196) who postulates that the younger son 'mirrors the life of Jesus' as he was perceived socially by those who adhered to purity codes (cf $L k$ 7:33-34). On this level the parable functions as a challenge to the dichotomy created by the temple cult between outsiders and insiders, Jesus himself being an outsider. A second level of reading is that of the earliest transmission of this parable, also situated in Palestine, but at a time shortly after the destruction of the temple in Jerusalem. The dichotomy between insiders and outsiders remains, but the audience changes, leading to a different challenge. Thirdly the parable can be read on the level of the community of Luke, situated in Asia Minor (cf Duling \& Perrin 1994:369). The audience is a mixture of Israelites and Greeks, shattering the previously clearly marked boundaries between clean and unclean, insiders and outsiders. However, the Lucan community is under threat from the ideology emanating from the synagogue under the influence of the Pharisees who regrouped at Jamnia after the destruction of the temple (cf Schmithals 1994:231; 237). The Pharisees continued to uphold the traditional purity codes, challenging any fellowship between Jews and non-Jews (cf Ac 11:2-3; 17:4-5). Our exposition of the parable of A Man Had Two Sons will be confined primarily to the last level of reading. How does Luke, in recalling the parable of A Man Had Two Sons, draw the audience into the world of the parable and challenge their worldview?

The parable consists of two acts juxtaposed together. Each act is introduced by one of the two sons referred to in the introductory verse: act one, verses 12-24

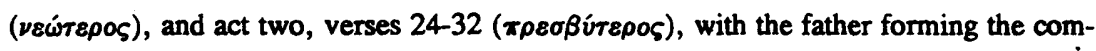
bining factor.

The introductory line (verse 11), with its reference to a younger and an older son (verse 11), immediately evokes a well-known repertoire of the Jewish cultural system: 
the mytheme of two-sons stories (Scott 1989:109). Stories of an older and a younger son are common in the Hebrew Bible: Cain and Abel, Ishmael and Isaac, Esau and Jacob, and so on. The younger son, although often a rogue who leaves his father's house, is usually portrayed as the favourite. The older son, in turn, is usually portrayed as the one not loved by the father (see, for example, Roger Syrén's [1993] book The forsaken first-born: A study of a recurrent motif in the patriarchal narratives). The favouritism shown by the father towards the younger son is countered by the law according to Deuteronomy 21:15-17. But despite this law, the line of Israel's inheritance is through the younger son. That this tradition even persisted in the folklore of Israel is seen in a passage from the Midrash of Psalms, commenting on Ps 9:1.

$R$. Berechiah said in the name of R. Jonathan: ... the verse means therefore that God has set love of little children in their fathers' hearts. For example, there was a king who had two sons, one grown up, the other a little one. The grown-up one was scrubbed clean, and the little one was covered with dirt, but the king loved the little one more that he loved the grown-up one.

(Scott 1989:112)

The mention of a father having two sons therefore clearly places this parable within a known story tradition, with the hearer supposedly knowing how the story will end: the younger son receives the father's blessing, the older son is rejected.

The anticipated roguish behaviour of the younger son is confirmed when he requests his portion of the property (verse 12). Reference to property evokes another element of the Jewish repertoire: that of the legal codes. The description of the younger son's behaviour creates tension. Although Jeremias (1977:128-129) and Linnemann (1966:75) argue for the commonality of the younger son's behaviour, this is not the case. Scott (1989:109) refers to Sirach 33:19-23, where a strong waming is given against the early division and disposition of property. The division of property belongs within the familial honour system. Honour was the pivotal value in first-century Palestine, much as money is in our society today. Honour determined a person's position in a family and society. A father, for example, would demand that his children do something; and in obeying the children would treat him honourably, honour being the socially proper and accepted attitude and behaviour (Malina 1981:25-50). Giving one's property away is the same as relinquishing one's place of honour and power. A father who, therefore, gives the right of disposition to a son is a fool. He runs the risk of 
losing his whole livelihood. Scott (1989:110) quotes Mishnah Baba Batrah 8, which contains an extended discussion of the order of inheritance. It is emphasised in this passage that disposition should only come into effect after a father's death. The situation described in the parable, although not unknown, as seen from the warning given in Sirach 33:19-23, is not ordinary and definitely not the norm. By giving the right of disposition the father puts his family honour in jeopardy, and the son, in requesting disposition, has in effect proclaimed his father dead. This is confirmed by the Greek text. The younger son requests his portion of the property (oivi $\alpha$ ) and the narrator remarks that the father divided his life (Bios) among them (Scott 1989:111).

The tension created by the intertwining of the two repertoires mentioned above puts the listener in a complex situation. On the one hand, the mytheme of two-sons stories leads him to identify with the younger son. On the other hand, the younger son clearly goes too far. This tension intensifies in the next verse (verse 13). Having gathered his possessions, the son departs to a foreign country. Departure always indicates a test, with the audience expecting the younger son to make good. But the test is failed miserably when the son does not increase his inheritance, but squanders it in wild and immoral living.

In the verses 14-16 the audience's patience with the younger son is tested to the limit. Although the famine might have drawn some sympathy from the listener, the son does what from a Pharisaic point of view is the worst thing he can do. Instead of looking for help in his own tribe, or at least in a Jewish community, he joins a foreign family. By doing this, his break with his family is complete. But even worse is to follow. In feeding pigs he also breaks with his religion. Feeding pigs was for a Jewish citizen a forbidden occupation. A well-known Jewish saying is: 'Cursed be the man who keeps swine' (Linnemann 1966:76). By coming into contact with these animals, the younger son could no longer keep the Sabbath day holy. The audience is shattered. Identification with the younger son becomes an infeasible option.

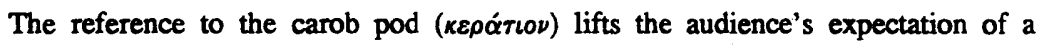
change in events. Scott (1989:115) refers to a rabbinic maxim which states that Israel needs carob to be forced to repentance. Verses 17-20a depict the long-awaited turn in events. Prompted by his hungry stomach, the younger son comes to his senses and weighs up his options. As he has forfeited his rights, both as a son by losing his inheritance, and as a Jewish citizen by attaching himself to a foreigner and feeding pigs, he decides to become a hired hand on his father's farm.

Although the mytheme of the younger son story causes an audience to expect the restoration of the younger son, the actions of the father are most unusual and unexpected (verses 20b-24). Like the younger son, the father now goes too far. In running 
towards his son the father violates his honour. It was beneath the dignity of an aged oriental to run (Linnemann 1966:77). Embracing and kissing are signs of forgiveness. The kiss on the cheek, in contrast to kissing the feet or the hand, is the sign of total and unreserved acceptance. Strikingly for the listener, the son's confession of guilt is not followed by a test of genuineness. Linnemann (1966:78) points out that strict demands were made of the penitent. Before he was fully accepted into the community, he had to show that his life had indeed changed for the better. Although the son proposes terms for restoration, he is interrupted by his father. The father accepts him unconditionally, not as a slave, but as a son, and restores him to his former status. The specific objects mentioned are all cultural clues designed to alert the hearer to the son's restoration within the father's honour' (Scott 1989:118). The son receives a robe, which is a special way of honouring a person. Jacob honours his younger son Joseph with the gift of a richly omamented robe ( $\mathrm{Gn} 37: 3$ ). The adjective $x \rho \hat{\omega}$ Tos (first, best) could refer to the robe of the father himself. The ring is probably a signet ring and signifies the bestowal of authority (Jeremias 1970:130). The shoes distinguish between a free man and a slave, who walked barefoot. The killing of the fattened calf correlates with the themes of both hunger and joy; a feast for the whole family. With the father's remark that his dead son is alive, and the once lost is now found, the restoration is complete.

With the introduction of the elder son (verse 25) the mytheme of the two-sons stories is recalled. The audience expect the elder son to live up to their expectation. This section (verses 26-30) is marked by spacial metaphors. The elder son is in the field, away from his father. He draws near to the house but does not enter it. As with the younger son, the father comes out of the house to meet the elder son. The elder son is angry because he who squandered his possessions and failed to provide for his father is enjoying a feast, which he as elder son who slaved for the father never enjoyed. Furthermore, within a limited-goods society (cf Malina 1981:71-93) the retum of the younger son could only be at the cost of the elder son.

The elder son's complaint centres around the theme of honour. In restoring the younger son to his former honour and allowing him to be supported from the property, the father has failed to live up to the demands of honour (Scott 1989:121). By refusing to eat with his father and brother, he challenges his father's honour and shames him. His break with the family is signified in the manner in which he declines to refer to the younger son as 'my brother', but calls him 'your son' (verse 30).

Vital to an understanding of this parable are the contrasting points of view (cf Scott 1989:119-122). The first hint of this is signalled by the sudden change from indirect to direct speech in the servant's report to the elder son. By giving the servant's report in direct speech the word viós (son) is replaced with $\dot{\alpha} \delta \varepsilon \lambda \phi o ́ s$ (brother), marking an im- 
minent challenge by the elder son to the father's point of view. For the elder son, the younger son is a rogue and a profligate. For the father, however, the younger son is one who was lost and has been found. The elder son sees himself as a faithful slave of the father, never breaking a commandment. The audience, however, sees him as a selfish and self-righteous pretender.

Critical, and in the past often overlooked, is the father's point of view of the elder son. He sees him not as a faithful slave, but rather 'as a companion ["always with me"] and a co-owner of the farm ["all that is mine is yours"]' (Scott 1989:121). The father does not reprimand the elder son, as the audience will have expected. Instead he confirms that he inherits all (verse 31). Lovingly he calls him róxvov (child). Although the parable always maintains a careful legal view, the legal titles are clearly dismissed by the father in his behaviour towards his two sons, with whom he deals as children. The loving response to the elder son as 'child' correlates to the embracing and kissing of the younger son. The father does not choose between the two. He embraces both. With regard to upholding his honour within the set rules of society, the father is a failure, but in showing mother-like compassion for his children, he is a success.

Notably the parable is without an ending. Whether the elder son goes in or stays outside, remains an open question, challenging the audience.

\subsection{The symbolism of the kingdom and its challenge to a conventional worldview} The question of how the parable relates to the mytheme of two-sons stories is central to an understanding of the symbolism of the kingdom. Does it support or challenge the mytheme? In Jewish literature the mytheme functioned on various levels. Scott (1989: 123) shows how with the patriarchal narratives, the mytheme was incorporated to explain why God chose Israel above other nations, even when Israel wandered from his way. The answer given by the mytheme is: It has nothing to do with what Israel did; as with the younger son, God simply favoured Israel. This is illustrated by Malachi 1: 2-3, where God declares his love for Jacob, the younger son, and his hatred of Esau, the elder son.

Paul, on the other hand, 'turns the two-sons mytheme against Israel of the flesh to argue that the Gentiles, the sons of promise, the younger sons, are part of God's grace' (Scott 1989:124). To prove his point, Paul uses primarily the narratives of Isaac and Jacob. God's promise to Abraham flows through Isaac, the younger son $(R m$ 9:7; G1 4:28), and Rebecca is told that her elder son will serve the younger ( $R m$ 9:12). In line with Paul's adoption of the two-sons stories, early Christians (at the time of Luke) used them to explain their own chosen status, they being the younger sons. 
Scott (1989:125) points out that the 'parable's scandal derives from its subversion of the mytheme's power to resolve between the chosen and the rejected'. The mytheme leads the listeners to identify with the younger son. Once they identified with him, they are put under severe strain by a string of highly improbable events accentuated by exaggerations or hyperbole. Just when for the listeners identification with the younger son is no longer a viable option, the father enters the plot and accepts the younger son, even before he can show repentance. Despite his actions, the younger son is not an outsider, but an insider. The audience anticipates the elder son's rejection. He is, from the perspective of the audience, the outsider who refuses to enter the house. But contrary to the listeners' expectations, the elder son is not hated by the father. He is neither banished - 'I am always with you' - nor is his inheritance taken away from him or reduced in any way: 'All that is mine is yours'. To the dismay of the audience, and contrary to the two-sons stories, the father does not decide between his two sons. He rejects no one, but chooses both. The narrator lures the listeners into the world of the parable, allows them to identify with one or the other character in the parable, but then, by repeated use of diaphor the narrator confronts and changes their point of view so that it does not conform to that of the leaders of Israel.

Notably on the level of reading of the historical Jesus, the roles of insiders and outsiders are reversed. Those who adhered to purity codes, the elder son, were the insiders, and those who associated with sinners, the younger son, were the outsiders. At the time of Luke, however, Christians no longer wanted to think of themselves as outsiders, but saw themselves as the insiders, those who were saved by faith in Christ, and the others as outsiders (Funk 1996:194). Critical for Luke is not the reversal of roles in the one or the other way, but the unity of God's family and the all-inclusiveness of God's kingdom. Accordingly, the kingdom of God is symbolized in this parable not as something that divides but as unifying. It is not particularist, but universal (Scott 1989:125). In the kingdom of God some are not chosen and others rejected. The kingdom is open to everyone.

This parable is a classical example of how story telling, metaphorical in nature, is used to challenge a conventional worldview. In his recently published work Jesus and the victory of God, Thomas Wright (1996:126-131) argues that this parable only makes sense as a profoundly subversive retelling of. Israel's story. As such, the younger son does not only mirror the journey of Jesus (cf Funk 1996:189), but that of Israel itself. There is a marked resemblance between this story of the younger son who goes of in disgrace into a far country and then returns home to find his welcome being challenged by an elder brother, and the story of Israel's exile and restoration. Although the people had returned from exile, the great prophecies of restoration has at the time of Jesus not 
yet been fully realized. For Wright (1996:127) the story of the prodigal son quite simply states: The hope of Israel's glorious restoration is now being fulfilled. This is, however, done in a highly paradoxical fashion, in Jesus' own ministry. The real restoration is taking place under the noses of the elder brothers, without them realizing it.

The parable of A Man Had Two Sons, a Sondergut of Luke, illustrates Luke's universalism, which features throughout his two-volume work (cf Duling \& Perrin 1994: 369-371). Boundaries between rich and poor, clean and unclean, insider and outsider, Jew and Gentile, epitomising aspects of the conventional Jewish worldview, are broken down. These 'boundary-crossing' stories are framed by Jesus' genealogy extending back to Adam ( $L \mathrm{k}$ 3:23-28), and the description of the Gospel of Jesus spreading into Gentile country, to the 'ends of the earth' (Ac 1:8). By retelling the story of A Man Had Two Son's, Luke challenges the exclusive worldview of particularly the leaders of Israel. The story accentuates that Israel's restoration is not restricted to Israelites alone, but once completed includes everyone, Israelites and Gentiles alike.

Wright (1996:128) points to an interesting parallel between Luke 15 and Acts 15 (the council at Jerusalem). In both stories people are being welcomed in from beyond the socially and religiously defined boundaries. The crucial passage in Acts 15 (verses 16-17) is a quotation from Amos 9:11-12. Amos foretells that Jahweh's return will result in the rebuilding of David's dwelling place, in order that all other people may seek him, even all the Gentiles. The reasoning behind this quotation is this: Because Israel's restoration has been completed in and through Jesus, it is time for the Gentiles also to come in. God's welcoming home is extended to the ends of the earth.

By retelling the story of A Man Had Two Sons within his own context, Luke challenges the leaders of Israel and others to 'enter' and to accept the all-inclusiveness of God's kingdom. Like Luke's two-volume work, the parable remains open-ended. As contexts change, and as roles are reversed, this parable will continue to invite readers to enter into dialogue and to face the challenge posed by it.

\section{Works Consulted}

Duling, D C \& Perrin; N 1994. The New Testament: Proclamation and parenesis, myth and history. Forth Worth: Harcourt Brace College Publishers.

Funk, R W 1966: Language, hermeneutic, and word of God. New York: Harper \& Row.

1996. Honest to Jesus: Jesus for a new millennium. San Francisco: Harper. (A Polebridge Book.)

Herzog, W R 1994. Parables as subversive speech: Jesus as pedagogue of the oppressed. Louisville: Westminster/John Knox Press. 
Jeremias, J 1970. Die Gleichnisse Jesu. Göttingen: Vandenhoeck \& Ruprecht.

Kissinger, W S 1979. The parables of Jesus: A history of interpretation and bibliography. Metuchen: Scarecrow Press.

Linnemann, E 1966. Parables of Jesus: Introduction and exposition. London: SPCK.

Lenski, G, Lenski, J \& Nolan, P 1991. Human societies: An introduction to macrosociology. New York: McGraw-Hill.

Malina B J 1981. The New Testament world: Insights from cultural anthropology. Louisville: John Knox Press

Martin, J P 1987. Toward a post-critical paradigm. NTS 33, 370-385.

Mouton, J \& Marais, H C 1996. Basic concepts in the methodology of the social sciences. Pretoria: Human Science Research Council.

Perrin, N 1976. Jesus and the language of the kingdom: Symbol and metaphor in New Testament interpretation. Philadelphia: Fortress Press.

Pelser, G M M 1994. Hermeneutiek: Vanaf die vroegste kerk tot by die Nuwe Hermeneutiek. Unpublished notes, Department of New Testament Studies (Sec A), University of Pretoria.

Peters, T 1992. God - the world's future: Systematic theology for a postmodern era. Minneapolis: Fortress.

Schmithals, W 1994. Theologiegeschichte des Urchristentums: Eine problemgeschichtliche Darstellung. Stuttgart: Verlag W Kohlhammer.

Ssott, B B 1981. Jesus, symbol-maker for the kingdom. Minneapolis: Fortress.

1989. Hear then the parable: A commentary on the parables of Jesus. Minneapolis: Fortress.

Syren, R 1993. The forsaken first-born: $A$ study of a recurrent motif in the patriarchal narratives. Sheffield: JSOT Press. (JSOT Supplement Series 133.)

Van Aarde, A G 1994. The historical-critical classification of Jesus' parables and the metaphoric narration of the wedding feast in Matthew 22:1-14, in God-with-us: The dominant perspective in Matthew's story, and other essays, 229-247. Pretoria: University of Pretoria. (HTS Suppl 5.)

Van Huyssteen, J W 1989. Theology and the justification of faith: The construction of theories in Systematic Theology. Grand Rapids: Wm B Eerdmans.

Wilder, A N 1971. Early Christian rhetoric: The language of the gospel. Cambridge, Mass.: Harvard University Press.

Wright, N T 1992. The New Testament and the people of God. London: SPCK. 1996. Jesus and the victory of God. London: SPCK. 